\title{
Wind Turbine Incident/Complaint Reports in Ontario, Canada: A Review - Why Are They Important?
}

\author{
Carmen M. Krogh ${ }^{1,2}{ }^{*}$ E. Jane Wilson ${ }^{3}$, Mary E. Harrington ${ }^{1,2}$ \\ ${ }^{1}$ The Society for Wind Vigilance, Member of the Board of Directors, Killaloe, Canada \\ ${ }^{2}$ Magentica Research Group, Member of the Board of Directors, Killaloe, Canada \\ ${ }^{3}$ Wind Concerns Ontario, Wellington, Canada \\ Email: *carmen.krogh@gmail.com
}

How to cite this paper: Krogh, C.M., Wilson, E.J. and Harrington, M.E. (2019) Wind Turbine Incident/Complaint Reports in Ontario, Canada: A Review-Why Are They Important? Open Access Library Journal, 6: e5200.

https://doi.org/10.4236/oalib.1105200

Received: January 22, 2019

Accepted: February 15, 2019

Published: February 18, 2019

Copyright $\odot 2019$ by author(s) and Open Access Library Inc.

This work is licensed under the Creative Commons Attribution International License (CC BY 4.0).

http://creativecommons.org/licenses/by/4.0/

\begin{abstract}
Background: The introduction of industrial wind turbines into quiet rural environments in Ontario, Canada has resulted in complaints about environmental noise and adverse health effects. Ontario has a process whereby residents can report noise to government. Official government records of Incident Reports/Complaints submitted by residents living near operating wind turbine installations were obtained through a Freedom of Information request. This article presents an evaluation of this process while commenting on the significance of Incident Reports/Complaints. Methods: Government records of Incident Reports/Complaints were analysed. Peer reviewed publications, conference presentations, judicial proceedings, government resources, and other sources were evaluated and considered in context with the topic under discussion. Objectives: The purpose of this article is to present the role and significance of Incident Reports/Complaints and discuss the value of these when assessing outcomes related to the introduction of wind turbines into a quiet rural environment. Results: Government records document 4574 Incident Reports/Complaints received by Ontario's hotline (20062016). There was no ministry response to over $50 \%$ of more than 3000 submitted formal complaints (2006-2014). Another 30\% were noted as "deferred" response. Only $1 \%$ of the reports received a priority response. Provincial Officers noted in summary reports that people were reporting health effects such as: headache, sleep deprivation, annoyance, and ringing or pressure sensation in the head and ears. Health effects were reported many times including those occurring among children. Discussion: In the case of wind power installations, Incident Reports/Complaints are an important source of information for evaluating outcomes of introducing a new noise source into a
\end{abstract}


quiet rural environment and are a form of public health surveillance. These reports can highlight risks to a healthy community living environment, act as an early warning system, and aid in evaluation of government policy initiatives. They may also be used before legal tribunals in public or private actions.

\section{Subject Areas}

Public Health

\section{Keywords}

Industrial Wind Turbines, Windmills, Incident Reports and Complaints, Public Health Surveillance

\section{Introduction}

On May 14, 2009, Ontario, Canada's Green Energy and Green Economy Act (Bill 150) (GEA) received Third Reading and Royal Assent [1]. It was expected that the legislation would encourage wind energy development in Ontario.

The preamble of the GEA stated:

The Government of Ontario is committed to fostering the growth of renewable energy projects, which use cleaner sources of energy, and to removing barriers to and promoting opportunities for renewable energy projects and to promoting a green economy [2].

Prior to the enactment of the Green Energy Act, several industrial wind turbine (IWT) projects were already operating in proximity to family homes [3] [4]. Some families had advised Ontario authorities that they were experiencing adverse health effects ([5], p. G-664; [6], p. G-547; [7]).

Ontario established a process for reporting "noise pollution" which includes a "Public pollution reporting hotline" [8]. The "hotline" was managed by the former Ministry of Environment and Climate Change (MOECC), now renamed the Ministry of Environment, Conservation and Parks (MECP).

Residents have used this process to formally file complaints about environmental noise and the associated adverse health effects from the introduction of wind turbines (IWT) into their living environment. Internally, the Ontario government refers to these complaints as Incident Reports [7].

In order to evaluate effectiveness of the reporting process regarding wind turbine noise, government Incident Reports/Complaints records were obtained through a request made under the province of Ontario's Freedom of Information (FOI) legislation by the community group coalition Wind Concerns Ontario (WCO). Findings were presented during a citizen appeal of a wind power project held before the Ontario Environmental Review Tribunal (ERT). Testimony included factual evidence based on the official government records of Incident Reports/Complaints submitted by residents living in proximity to oper- 
ating IWT installations [7].

This article presents a brief analysis of the government records provided. It comments on their value in assessing outcomes related to the introduction of IWTs into a quiet rural environment and discusses the role and significance of Incident Reports/Complaints records in general.

\section{Method}

Government records of Incident Reports/Complaints records were analysed. A snapshot of findings is presented. Peer-reviewed publications, judicial proceedings, government resources, and other sources were evaluated and considered in context with topic under discussion.

\section{Results}

Findings were presented during a citizen appeal of a wind power project held before the Ontario Environmental Review Tribunal (ERT). Testimony included factual evidence based on the official government records of Incident Reports/Complaints submitted by residents living in proximity to operating wind turbine installations [7].

An analysis of the records provided by the former Ministry of Environment and Climate Change (MOECC) indicates:

The total number of Incident Reports filed officially with the MOECC between 2006 and the end of 2016 was 4574.

For the period 2006-2014, the records showed that in more than $50 \%$ of the more than 3000 formal complaints, there was no ministry response. Another 30\% were noted as "deferred" response-with no definition or criteria as to what that means. In fact, only $1 \%$ of the reports received a "priority" response [7].

In addition, a review of the documents included summary reports with detailed notes from the ministry's Provincial Officers that people were reporting adverse health effects such as: headache, sleep deprivation, annoyance, and ringing or pressure sensation in the head and ears. These health effects were reported many times, and included children [7].

Testimony during the appeal also noted that it appeared the total number of Incident Reports was likely incomplete:

The total number of IRs provided for 2006-2016 was 4574 but that number is almost certainly not complete. Several offices (Cornwall, Windsor) did not routinely give out tracking numbers, for example, so their records would not have been provided in the Freedom of Information request.

Wind Concerns Ontario also conferred with members of the coalition, people who had made reports to the Spills Action Centre and received IR numbers-upon cross-checking this information personally, it appears that in some cases these were not represented in the documents provided [7]. 
Other data, not presented during testimony, show that in the years 2006-2009, before Ontario's wind power program officially began, there were more than 600 recorded complaints of wind turbine noise. The percentage of IWT noise complaints among the total pollution reports submitted by Ontario residents rose from $1 \%$ to $9 \%$ during the four years ([9], pp. 4-5).

In Ontario, government approvals of renewable energy facilities required that the operators of these facilities address all complaints about the IWTs and other features, and report to the government all measures taken to prevent recurrence of the situation causing the complaints. It may be that residents were complaining to the wind power operators in addition to the government or, when no action was taken, only to government in the hope of resolution ([9], p. 5).

Documentation of citizen noise reports received from the government shows that in the beginning, staff of the province's environment ministry made an attempt (though apparently without resolution) to respond to the reports of excessive noise and other effects of wind turbine noise emissions. This may have conflicted with the government's "green energy" policy as the efforts appear to have changed from response to issues management as the response rate to complaints declined to 6.9 percent in 2015-2016, from 40 percent in 2006-2014 ([9], p. 4).

Copies of staff training materials in Ontario which were received in the FOI request show that employees were given specific directions from management as to what action, if any, to take. For example, in one PowerPoint training session, staff was directed not to treat wind turbine noise as tonal ([9], p. 9). It is possible the reason for this, could have been that according to the government noise measurement protocol, a $5 \mathrm{dBA}$ penalty would have to be applied to noise measurements in the case of tonal or cyclical noise emissions, in which case a turbine might have been found non-compliant with regulations.

Notes from staff in summary reports of Incident Reports also indicated that staff recommendations to middle and upper management to issue orders for noise abatement or other actions were ignored ([10], p. 12).

It appears that the process of filing wind turbine Incident Reports and its purpose for addressing concerns about effects on health and safety may have resulted in more reports than expected and may have been dissonant with stated government policy objectives to promote "green" energy.

\section{Discussion}

\subsection{Incident Reports/Complaints: An Early Warning System}

In Ontario, numerous Incident Reports/Complaints about environmental noise and adverse health effects associated with IWTs have been submitted to the government.

Incident Reports are typically used to record details of accidents, patient injury and other unusual events that occur in a health care facility [11]. These reports could be used in court when dealing with issues such as liability or insurance claims [11] [12]. Most hospitals require that the nursing staff fill out inci- 
dent reports "when a problem in medical care delivery has occurred" [13].

Complaints can serve as useful monitoring and evaluation tools that expectations of a new policy initiative or programme are not being met. Kroening et al. (2015) comment: "Patient complaints can highlight specific risks to patient safety and act as an early warning system" [14].

In addition, complaints may be seen as part of an effective public health surveillance system. According to the Centers for Disease Control "The purpose of evaluating public health surveillance systems is to ensure that problems of public health importance are being monitored efficiently and effectively" [15].

The ultimate test for a government complaint process is trust in authorities to respond and protect the public. Formal complaints can highlight risks to a healthy community living environment, act as an early warning system, and aid in an evaluation of government policy initiatives. However, if no action is taken or if the issues are not acknowledged, the value of an Incident/Complaint process may be lost.

\subsection{Noise and the Annoyance Pathway-Noise Induced End Points and Health Effects}

A significant number of the Ontario reported complaints about wind turbine noise refer to adverse health effects and it is important to point out that authorities and the wind power industry have attributed this to "annoyance" [16] [17].

Regarding community noise, Health Canada states:

The most common effect of community noise is annoyance, which is considered an adverse health effect by the World Health Organization [18].

In everyday language, some may consider the term "annoyance" trivial. However, in terms of health, an annoyance pathway can lead to health problems and is acknowledged as an adverse health effect.

A review by Jeffery et al. (2014) comments that regarding indicators such as complaints and percent highly annoyed, Health Canada states that it "considers the following noise-induced endpoints as health effects: noise-induced hearing loss, sleep disturbance, interference with speech comprehension, complaints, and change in percent highly annoyed" [19].

A hearing convened by the Australian Administrative Appeals Tribunal (December 4 , 2017) states evidence justifies the conclusions that:

...noise annoyance is a plausible pathway to disease

There is an established association between WTN annoyance and adverse health effects (e.g., this was established by the Health Canada study)

There is an established association between noise annoyance and some diseases, including hypertension and cardiovascular disease, possibly mediated in part by disturbed sleep and/or psychological stress/distress [20]

Regarding a causal chain through annoyance, research results indicate:

...confirmed, on an epidemiological level, an increased health risk from 
chronic noise annoyance [21]

...confirms the thesis that for chronically strong annoyance a causal chain

exists between the three steps health-strong annoyance-increased morbidity [22]

The Canadian Wind Energy Association and American Wind Energy Association Expert Panel considered the existing literature on wind turbine noise and health and commented that "wind turbine syndrome' symptoms are not new and have been published previously in the context of 'annoyance" and are the "well-known stress effects of exposure to noise" [17].

Hahad et al. (2018) considered noise-induced annoyance "'dose-dependently" associated with the common arrhythmia atrial fibrillation" which "may represent an important cardiovascular risk factor" [23].

In a study about air traffic noise, Maziul, Job and Vogt (2015) comment "the ongoing controversy on the relation between annoyance and complaint behavior seems not resolved yet" and propose "Adequate and efficient ways to handle annoyance?!" which includes establishing "further investigations" to complement complaint data.

Nevertheless, other ways to complement complaint data have to be developed. It has to be assumed that the large number of annoyed residents, who do not call a noise complaint line, either cope differently or do not cope at all. Therefore, further investigation is called for in which way these residents handle their annoyance and what might actually help them to cope. In order to establish new ways representative social surveys or personal interviews could be conducted to address all residents and find out their preferences. Also, the residents' concern relating to the successfulness and efficiency of noise complaint lines needs to be considered. Annoyed residents trying to cope by calling the noise complaint line and feeling insufficiently treated might even become more annoyed. It is important when operating noise complaint lines to respond to complainants at once and to be precise at all times, especially the first time people complain [Emphasis added] [24].

While the study by Maziul, Job and Vogt (2015) applies to air traffic noise, the suggestions for enhancing a complaints process could be applied to the noise annoyance being reported by residents who live near wind turbines.

\subsection{Public Health Surveillance and Vigilance Monitoring: Why Do They Matter?}

Public health surveillance is an ongoing process regarding "a health-related event for use in public health action to reduce morbidity and mortality and to improve health". Complaints may be seen as part of an effective public health surveillance system [15].

Health Canada provides context related to Incident Reports/Complaints and 
encourages medical device users to report "device-related incidents directly to Health Canada by completing a Health Product Complaint Form" [25]. In keeping with this, Ontario government records demonstrate that the complaints from residents living near wind energy projects are also considered "Incident Reports". This was confirmed in the government documents obtained by the community group coalition Wind Concerns Ontario (WCO) [7].

The Canada Vigilance program is a post-market surveillance system to ensure the "benefits of the products continue to outweigh the risks" and "collects and assesses reports of suspected adverse reactions to health products marketed in Canada" [26]. Anyone, such as manufacturers, professionals, and consumers can report adverse reactions to Health Canada and its partners [25]. Health products include items such as: prescription and non-prescription medications, natural health products, biologics, radiopharmaceuticals, medical devices, pesticides, and disinfectants (with disinfectant claims) and sanitizers.

Health Canada advises that reporting adverse effects may contribute to identifying previously unrecognized rare, or serious adverse reactions; support for making changes in product safety information; or taking other regulatory actions such as the withdrawal of a product from the Canadian market. Health Canada assures those reporting an effect are encouraged to do so even if they are not certain "a particular health product was the cause" [27].

During a meeting held with staff from the Office of the Minister of Health in 2009, attendees McMurtry and Krogh advised there was a lack of surveillance regarding wind turbines and recommended implementing a federal Canada-wide surveillance program to encourage the reporting of adverse health effects associated with IWT. It was suggested it could be called Canada Wind Vigilance and the wind energy industry would be obligated to provide government with records of any submitted reports. While Health Canada representatives indicated consideration would be given to this recommendation [28] there is no indication adverse health effects associated with living near IWT is being considered by a formal Canadian government monitoring/vigilance program.

Other programs such as the VAERS (Vaccine Adverse Event Reporting System) serve as an "early warning system to detect possible safety issues with US vaccines by collecting information about adverse events (possible side effects or health problems) that occur after vaccination". Those reporting events or health problems do not have to be sure the event or health problem was a result of a vaccination [29].

VAERS encourages anyone including doctors, nurses, vaccine manufacturers, and members of the general public to submit a report. VAERS is intended among other processes to: monitor increases in known side effects, identify potential risk factors, watch for unexpected patterns to adverse event reports, and provide a national monitoring system [30].

VAERS notes one of the limitations is that "Serious adverse events are more likely to be reported than mild side effects" [31]. Based this observation, it suggests that Ontario residents may be reporting "serious adverse events" rather 
than minor ones. There is an opportunity for government authorities to consider the 4574 Incident Reports/Complaints as an indicator that the current noise guidelines and setbacks for industrial wind turbines are not performing as expected.

\subsection{General Observations}

In Ontario, most of the Renewable Energy Approvals for industrial wind power projects have been appealed and hearings held before the ERT (Environmental Review Tribunal). Factual evidence of Incident Reports/Complaints was presented during the appeal of the "Nation Rise" power project. Of interest, the lawyer representing the government and the Director of the environment ministry defended the government approval of the power project in question, declaring the reports to be "hearsay":

[125] ... the Director asserts that [the] study is based on hearsay evidence obtained by viewing MECP reports and that, while hearsay evidence is admissible in administrative hearings, it still must be credible. ... The Director submits that ... no conclusions can be drawn from self-reported complaints that have not been assessed or confirmed... [32].

This observation raises several points related to "anecdotal hearsay evidence." Since the testimony was based on official government records, it is interesting these were viewed as "hearsay evidence".

As noted in Sections 4.1 Incident Reports/Complaints: an early warning system and 4.3 Public Health Surveillance and Vigilance Monitoring: why do they matter? there is an opportunity to consider them "an early warning system" while supporting health surveillance. Thousands of "self-reported" complaints form the basis of credible Incident Reports-their existence should be taken seriously and are in themselves consequential.

Anecdotal evidence and causal association has been discussed in a publication by the British Medical Journal:

Many adverse drug reactions are first reported anecdotally. Anecdotal reports, by which we mean either individual cases or small case series, are generally regarded as providing poor quality evidence. They therefore usually require formal verification through robust epidemiological studies or clinical trials, although a minority are actually verified. However, we propose that some adverse drug reactions are so convincing, even without traditional chronological causal criteria such as challenge tests, that a well documented anecdotal report can provide convincing evidence of a causal association and further verification is not needed. Such reactions could serve as gold standards for use, for example, when validating pharmacovigilance systems or assessing the quality of systematic reviews of adverse drug reactions and the methods used to perform them. Specificity of an adverse drug reaction has previously been discussed as a concept ... but to our knowledge has never been fully developed [33]. [Emphasis added] 
Citizens have been led to expect their communications with government and submitting Incident Reports and Complaints would lead to action. For example, in 2017, Ontario's environment minister told the Legislature "When people call ... [staff] respond quickly and they enforce the law... No one should have to suffer noise or noise pollution from any source, and certainly not wind turbines in their community" [34].

\section{Conclusions}

Those submitting Incident Reports/Complaints look forward to resolution and remedy to their satisfaction as soon as possible. In the meantime, based on the review of the Ontario Government documents, the Incident Reports/Complaints file is persuasive. It appears that the government has sufficient information to regard wind turbine noise emissions as a problem of public health importance and to dedicate efforts towards resolution.

Indications are that under Section 9 of the Ontario EPA (Environmental Protection Act) warrants an enforcement response from government. Section 1(1) defines "adverse effect", specifically, to mean one or more of:

1) Impairment of the quality of the natural environment for any use that can be made of it,

2) Injury or damage to property or to plant or animal life,

3) Harm or material discomfort to any person,

4) An adverse effect on the health of any person,

5) Impairment of the safety of any person,

6) Rendering any property or plant or animal life unfit for human use,

7) Loss of enjoyment of normal use of property, and

8) Interference with the normal conduct of business [35].

The evidence continues to indicate that the current Ontario IWT noise guidelines and setbacks are not working as expected. There is an opportunity for the Ontario government to enforce the EPA and:

- Acknowledge that many Ontario families are experiencing adverse effects from living near IWT;

- Consider the formal Incident Reports/Complaints as an early warning and public health surveillance tool;

- Review its noise guidelines to ensure they are protective of health;

- Ensure enforcement of existing regulations; and

- Take action such as issuing orders for regulatory abatement and possible shutdown of IWTs which are affecting families.

Records of Incident Reports and other forms of complaint are a valuable tool on the evaluation of programs and particularly where they are related to health, should guide policy and action to protect health.

\section{Acknowledgements}

The authors declare they had no actual or potential competing financial inter- 
ests, received no funding and volunteered their time during the research and writing of this paper. Authors Krogh and Harrington are volunteers and members of the Board of Directors of the Society for Wind Vigilance, a self funded Federally Incorporated Not-For-Profit organization and are volunteers and members of the Board of Directors for the Magentica Research Group, a self-funded Federally Incorporated Not-For-Profit organization. Author Wilson is a volunteer and President of Wind Concerns Ontario, a Federally Incorporated Not-For Profit organization, operating as Wind Concerns Ontario. In all cases, Board members volunteer their time and do not receive any financial remuneration for their services. The authors acknowledge Wind Concerns Ontario which obtained and analysed the Incident Report data. Wind Concerns Ontario is a not-for-profit coalition of 30 community groups and hundreds of individuals and families, working to improve awareness of the impacts of industrial-scale wind turbines on the economy, environment, and human health. This article is dedicated to individuals and families from around the world who are reporting adverse health effects associated with the presence of industrial scale wind turbines in proximity to their living and work environments. We thank the peer reviewers who provided professional expertise and helpful comments during the review process.

\section{Conflicts of Interest}

The authors declare no conflicts of interest regarding the publication of this paper.

\section{References}

[1] Overview of Ontario's Green Energy Act (2009) Prepared by Richard D. Lindgren. Canadian Environmental Law Association. https://www.cela.ca/newsevents/fiche-d\%E2\%80\%99information/overview-ontarios -green-energy-act

[2] Green Energy Act (2009) Chapter 12. Schedule A. An Act to Enact the Green Energy Act, and to Build a Green Economy, to Repeal the Energy Conservation Leadership Act, 2006 and the Energy Efficiency Act and to Amend Other Statutes. http://www.e-laws.gov.on.ca/html/source/statutes/english/2009/elaws_src_s09012_e .htm

[3] Krogh, C.M.E. (2011) Industrial Wind Turbine Development and Loss of Social Justice? Bulletin of Science Technology \& Society, 31, 321.

http://bst.sagepub.com/content/31/4/321 https://doi.org/10.1177/0270467611412550

[4] Krogh, C.M.E., Gillis, L., Kouwen, N. and Aramini, J. (2011) WindVOiCe, a SelfReporting Survey: Adverse Health Effects, Industrial Wind Turbines, and the Need for Vigilance Monitoring p. 335. Bulletin of Science Technology \& Society, 31, 334. http://bst.sagepub.com/content/31/4/334 https://doi.org/10.1177/0270467611412551

[5] Legislative Assembly of Ontario First Session, 39th Parliament. Report Journal of Debates (Hansard) (2009) Standing Committee on Green Energy and Green Economy Act, 2009. David Orazietti, Chair, Testimony by Dr. Robert McMurtry p. 
G-664.

https://www.ola.org/en/legislative-business/committees/general-government/parlia ment-39/transcripts/committee-transcript-2009-apr-22\#P68_2635

[6] Legislative Assembly of Ontario First Session, 39th Parliament. Report Journal of Debates (Hansard) (2009) Standing Committee on Green Energy and Green Economy Act, 2009. David Orazietti, Chair. Testimony by Ashbee B., p. G-516 and the Ripley Group, p. G-547.

https://www.ola.org/en/legislative-business/committees/general-government/parlia ment-39/transcripts/committee-transcript-2009-apr-15\#P1296_397237

[7] Concerned Citizens of North Stormont v. Director, Ontario, Ministry of Environment and Climate Change. Ontario Environmental Review Tribunal. Renewable Energy Approval Appeal Case No. 18-028. Witness Statement by Wilson J. (2018) PDF Copy Available on Request.

[8] Ontario Ministry of Environment. Spills Action Line. https://www.ontario.ca/page/report-pollution-and-spills

[9] Wind Concerns Ontario (2017) Response to Wind Turbine Noise Complaints: A Report on Incident Records Released under Ontario Freedom of Information and Privacy Act. 4-5.

http://www.windconcernsontario.ca/wp-content/uploads/2017/05/NoiseResponseR eport-FINAL-May9.pdf

[10] Wind Concerns Ontario (2018) Response to Wind Turbine Noise Complaints, Second Report Noise Complaints 2015-2016. 12.

http://www.windconcernsontario.ca/ontario-government-failed-to-respond-to-win d-turbine-noise-reports-documents-show/

[11] What Is an Incident Report-Nursing Crib. Perioperative Nursing (2010) By Daisy Jane Antipuesto RN, MN.

https://nursingcrib.com/perioperative-nursing/incident-report/

[12] Why Incident Reports Are a Must. NSO Insurance-Risk Education-NSO. https://www.nso.com/Learning/Artifacts/Articles/Why-incident-reports-are-a-must

[13] Preventive Law in the Medical Environment-Incident Reports. Chapter 1. https://biotech.law.lsu.edu/Books/aspen/Aspen-INCIDENT.html

[14] Kroening, H.L., Kerr, B., Bruche, J. and Yardley, I. (2015) Patient Complaints as Predictors of Patient Safety Incidents. Patient Experience Journal, 2, 94-101. https://pxjournal.org/cgi/viewcontent.cgi?article=1052\&context=journal

[15] CDC (Centers for Disease Control, 2001). Updated guidelines for evaluating public health surveillance systems: recommendations from the guidelines working group. MMWR 2001; 50(No. RR-13). https://stacks.cdc.gov/view/cdc/13376

[16] Health Canada (2014) Health Canada's Wind Turbine Noise and Health Study. Summary of Results.

https://www.canada.ca/en/health-canada/services/environmental-workplace-health/ noise/wind-turbine-noise/wind-turbine-noise-health-study-summary-results.html

[17] Colby, W., Dobie, R., Leventhall, G., Lipscomb, D., McCunney, R., Seilo, M. and Søndergaard, B. (2009) Wind Turbine Sound and Health Effects: An Expert Panel Review. American Wind Energy Association and Canadian Wind Energy Association.

http://www.canwea.ca/pdf/talkwind/Wind_Turbine_Sound_and_Health_Effects.pdf

[18] Health Canada (2005) Community Noise Annoyance, Its Your Health. https://www.canada.ca/content/dam/hc-sc/migration/hc-sc/hl-vs/alt_formats/pacrb -dgapcr/pdf/iyh-vsv/life-vie/community-urbain-eng.pdf 
[19] Jeffery, R.D., Krogh, C.M.E. and Horner, B. (2014) Industrial Wind Turbines and Adverse Health Effects. Canadian Journal of Rural Medicine, 19, 21-26. http://www.ncbi.nlm.nih.gov/pubmed/24398354

[20] Administrative Appeals Tribunal (2017) Waubra Foundation vs. ACNC. Decision \& Reasons, Summary of the Effect of the Medical and Scientific Evidence. 143. https://waubrafoundation.org.au/wp-content/uploads/2017/12/Decision-4-Dec-17.pdf

[21] Niemann, H., Bonnefoy, X., Braubach, M., Hecht, K., Maschke, C., Rodrigues, C. and Robbel, N. (2006) Noise-Induced Annoyance and Morbidity Results from the Pan-European LARES Study. Noise Health, 8, 63-79.

http://www.noiseandhealth.org/article.asp?issn=1463-1741;year=2006;volume=8;iss ue $=31$; spage $=63$; epage $=79$; aulast $=$ Niemann https://doi.org/10.4103/1463-1741.33537

[22] Niemann, H. and Maschke, C. (2004) LARES Final Report Noise Effects and Morbidity. World Health Organization. http://www.euro.who.int/_data/assets/pdf_file/0015/105144/WHO_Lares.pdf

[23] Hahad, O., Beutel, M., Gori, T., Schulz, A., Blettner, M., Pfeiffer, N., et al. (2018) Annoyance to Different Noise Sources Is Associated with Atrial Fibrillation in the Gutenberg Health Study. International Journal of Cardiology, 264, 79-84. https://www.sciencedirect.com/science/article/pii/S0167527317371747 https://doi.org/10.1016/j.ijcard.2018.03.126

[24] Maziul, M., Job, R. and Vogt, J. (2005) Complaint Data as an Index of AnnoyanceTheoretical and Methodological Issues. Noise Health, 7, 17-27.

http://www.noiseandhealth.org/article.asp?issn=1463-1741;year=2005; volume=7;iss $\underline{\mathrm{ue}}=28$; ;page $=17$; epage $=27$; aulast $=$ Maziul

[25] Government of Canada. Health Canada. Adverse Reaction Reporting for Specific Products. Medical Devices.

https://www.canada.ca/en/health-canada/news/media-room/advisories-warnings/ad verse-reaction-reporting.html

[26] Government of Canada. Health Canada. Canada Vigilance Program. https://www.canada.ca/en/health-canada/services/drugs-health-products/medeffect -canada/canada-vigilance-program.html

[27] Government of Canada. Health Canada. MedEffect Canada. Adverse Reaction Reporting Information.

https://www.canada.ca/en/health-canada/services/drugs-health-products/medeffect -canada/adverse-reaction-reporting/adverse-reaction-reporting-adverse-reaction-re porting-information.html

[28] McMurtry, R.Y. and Krogh, C.M. (2009) Meeting with the Office of the Minister of Health. Meeting Notes.

[29] VAERS (Vaccine Adverse Event Reporting System). https://vaers.hhs.gov/about.html

[30] VAERS (Vaccine Adverse Event Reporting System). Frequently Asked Questions (FAQs). https://vaers.hhs.gov/faq.html

[31] VAERS (Vaccine Adverse Event Reporting System). Strengths and Limitations of VAERS Data. https://www.cdc.gov/vaccinesafety/ensuringsafety/monitoring/vaers/index.html

[32] Concerned Citizens of North Stormont v. Director, Ontario Ministry Environment, Conservation and Parks. Case 18-028. Decision. http://elto.gov.on.ca/tribunals/ert/decisions-orders/

[33] Aronson, J.K. and Hauben, M. (2006) Anecdotes That Provide Definitive Evidence. 
BMJ, 333, 1267-1269. https://www.bmj.com/content/333/7581/1267

[34] Hansard, Ontario Legislature, Oral Questions, Session: 41:2.

https://www.ola.org/sites/default/files/node-files/hansard/document/pdf/2017/2017 -04/house-document-hansard-transcript-2-EN-12-APR-2017_L068.pdf

[35] Environmental Protection Act, R.S.O. 1990, c. E.19.

https://www.ontario.ca/laws/statute/90e19? search=Environment+Protection+Act+ R.S.O.+1990\%2C+c.+E.19 